\title{
SeBASTIAN WACIĘGA
}

Małopolski Instytut Kultury w Krakowie, Polska - Malopolska Institute of Culture in Krakow, Poland

PIOTR WróBeL

Akademia Górniczo-Hutnicza w Krakowie - AGH University of Science and Technology in Krakow

VII Liceum Ogólnokształcące w Krakowie - Zofia Nałkowska High School no 7 in Krakow

III Społeczne Liceum Ogólnokształcące w Krakowie - Polska Community High School in Krakow, Poland

\section{Wybrane modele dyfuzji innowacji edukacyjnych w regionach}

\section{Selected Models of Diffusion of Educational Innovations in the Regions}

Streszczenie: Celem artykułu jest przedstawienie dwóch modeli rozprzestrzeniania innowacji edukacyjnych służących rozwijaniu i kształtowaniu kompetencji przedsiębiorczych w regionach oraz wsparcie procesu decyzyjnego dotyczącego wyboru modelu dyfuzji. Pierwszy z modeli nazywamy odgórnym (systemowym, instytucjonalnym), gdyż wykorzystuje on zastane struktury instytucjonalne (np. ośrodki doskonalenia nauczycieli) oraz system szkoleń kaskadowych rozszerzający zasięg użytkowania wypracowanych innowacji edukacyjnych, dzięki szkoleniom trenerów regionalnych. Drugi model rozprzestrzeniania innowacji nazywamy oddolnym (społecznościowym, pomocniczym), gdyż wykorzystuje on oddolną aktywność lokalnych podmiotów (np. organizacji pozarządowych) i opiera się na zasadzie pomocniczości. Pomocniczość zakłada, że dostarczenie innowacyjnych rozwiązań jest odpowiedzią na potrzebę działających już podmiotów lokalnych lub regionalnych i stanowi uzupełnienie oraz metodyczne wsparcie prowadzonej przez nich działalności edukacyjnej lub społecznej. Oba modele zostały przetestowane (obserwacje, studia przypadków) przez Małopolski Instytut Kultury w Krakowie we współpracy z partnerami, w ramach realizacji ogólnopolskich projektów edukacyjnych z wykorzystaniem ekonomicznych gier inspirowanych historią. Projekty te, zrealizowane dzięki wsparciu finansowemu Muzeum Historii Polski (2010, 2015) oraz Narodowego Banku Polskiego (2012-2013), bazowały zarówno na modelu odgórnym, jak i oddolnym. W ich ramach realizowano szkolenia za pośrednictwem ośrodków doskonalenia nauczycieli (model systemowy) oraz lokalne, oddolnie tworzone projekty w kształcie zaproponowanym przez zgłaszających się partnerów w regionach (model pomocniczy).

Abstract: The purpose of this article is to present two models of disseminating educational innovations for development and shaping entrepreneurial competences in regions and support for the decision-making process regarding the selection of the diffusion model. The first one is called institutional, since it uses existing institutional structures of educational sector and introduces the system of cascade trainings, augmenting the range of innovations through competent trainers (top-down model). The second model of disseminating innovations is called grassroots (social, subsidiarity based; bottom-up model), as it is driven by local activity existing in regions and realised in accordance with the subsidiarity principle. The concept of subsidiarity assumes that the supply of innovation solutions is the response for the need of active local agents in regions, as well as the supplementation and methodical support of their educational and social activity. Both models were tested (observations, case studies) by Malopolska Institute of Culture in Krakow (Poland) in cooperation with partners during the implementation of domestic 
educational projects with the use of economic games inspired by history. The projects were realised with financial support of the Polish History Museum $(2010,2015)$ and the National Bank of Poland (2012-2013) and embraced the bottom-up as well as the top-down model of innovation diffusion.

Słowa kluczowe: aktywność lokalna; dyfuzja innowacji; innowacja edukacyjna; pomocniczość; przedsiębiorczość; system oświatowy; zasada pomocniczości

Keywords: diffusion of innovation; educational innovation; educational system; entrepreneurship; local activity; principle of subsidiarity; subsidiarity

Otrzymano: 9 listopada 2017

Received: 9 November 2017

Zaakceptowano: 5 lipca 2018

Accepted: 5 July 2018

Sugerowana cytacja/Sugessted citation:

Wacięga, S., Wróbel, P. (2018). Wybrane modele dyfuzji innowacji edukacyjnych w regionach. Przedsiębiorczość-Edukacja [Entrepreneurship-Education], 14,460-472.DOI: 10.24917/20833296.14.31

\section{Wstęp}

Celem artykułu jest opis funkcjonowania i rozpatrzenie zasadniczych właściwości dwóch wybranych modeli dyfuzji innowacji edukacyjnych $\mathrm{w}$ regionach. Wnioski z obserwacji i doświadczeń Małopolskiego Instytutu Kultury w Krakowie z okresu 2007-2017 w zakresie rozprzestrzeniania historyczno-ekonomicznych gier zespołowych mogą posłużyć decydentom i podmiotom realizującym projekty edukacyjne $\mathrm{z}$ elementem wdrożeń innowacji w podmiotach partnerskich lub u beneficjentów tychże projektów. Użyteczność niniejszego opracowania dotyczy uwzględniania zalet i trudności związanych z wyborem tych modeli oraz dokonania optymalnego wyboru sposobu dyfuzji - stosownego do założonych celów i dostępnych form oraz zakresów działania. Decyzja o wyborze modelu dyfuzji uwzględnia zarówno obszar edukacji formalnej, realizowanej przez szkoły oraz instytucje powołane do ich wpierania (kuratoria oświaty, ośrodki doskonalenia nauczycieli), jak również obszar edukacji nieformalnej, który wypełniać mogą m.in. organizacje pozarządowe czy instytucje kultury.

Pojęcie wdrożenia innowacji odnosi się do działania w ramach jednej organizacji, natomiast dyfuzja innowacji dotyczy wdrożeń realizowanych przez wiele organizacji-użytkowników rozwiązań innowacyjnych. Miarą sukcesu innowacji może być liczba wdrożeń, jak również zasięg dyfuzji i zakres jej zastosowania w organizacjach dzięki samodzielnej adaptacji przez jej użytkowników. Skuteczna dyfuzja zależy nie tylko od popytu na innowacyjne rozwiązanie, ale również od sposobu jego upowszechniania, tj. informacji o nim, jakości szkoleń wdrożeniowych oraz kompetencji użytkowników innowacji, tak by sami znaleźli i rozwijali własne obszary zastosowania innowacji w swoich organizacjach.

W poniższym tekście skupimy się na dyfuzji innowacji o charakterze edukacyjnym, głównie w sektorze publicznym. Omówimy dwie metody dyfuzji innowacji wypracowane w Małopolskim Instytucie Kultury w Krakowie w latach 2007-2017. Dotyczyły one gier ekonomicznych inspirowanych dziedzictwem regionalnym, które rozpowszechniane były w skali ogólnopolskiej dzięki dofinansowaniu Muzeum Historii Polski (2010, 2015) oraz Narodowego Banku Polskiego (2012-2013). Gry symulacyjne Małopolskiego Instytutu 
Kultury: Chłopska Szkoła Biznesu (trzy wydania: 2010, 2012, 2015) oraz Oil City - galicyjska gorączka czarnego złota, w innowacyjny sposób łączyły edukację historyczną $\mathrm{z}$ edukacją z zakresu przedsiębiorczości ${ }^{1}$. Metoda edukacyjna wykorzystująca wiedzę historyczną we współczesnej edukacji ekonomicznej (ang. history based entrepreneurial learning) została przedstawiona szerzej w artykule S. Wacięgi z 2015 r. (Wacięga, 2015).

W artykule przedstawione zostaną dwa zasadnicze modele upowszechniania (dyfuzji) innowacji edukacyjnych: odgórny (instytucjonalny, systemowy) oraz oddolny (społecznościowy, pomocniczy). Prezentacja tych modeli poprzedzona zostanie doprecyzowaniem głównych pojęć, do których odwołuje się niniejszy tekst.

\section{Dyfuzja innowacji edukacyjnych - zarys pojęć}

Innowacja zasadniczo jest rozumiana dwojako: jako rezultat (produkt) pewnego procesu lub jako udoskonalenie przebiegu tego procesu. Pojęcie innowacji może odnosić się do „wszystkich sfer życia, począwszy od nowych rozwiązań dotyczących życia gospodarczego czy społecznego, a skończywszy na nowych prądach myślowych i kulturowych" (Dolińska, 2010: 13).

\section{Innowacja produktowa}

Innowacja produktowa rozumiana jest jako „wprowadzenie do produkcji wyrobów nowych lub też udoskonalenie dotychczas istniejących” (Innowacja i transfer..., 2005: 65). W tej definicji innowacji mieszczą się gry ekonomiczne Małopolskiego Instytutu Kultury w Krakowie, których innowacyjność polega na inspiracji wiedzą historyczną w prezentowaniu uniwersalnych zjawisk i praw ekonomicznych. Udoskonalenie polega również na tym, że wymienione wyżej gry mogą być rozgrywane przez duże grupy, nawet do 30 osób, co powoduje, że są one użytecznymi narzędziami edukacyjnymi dla szkół oraz dla podmiotów prowadzących szkolenia dla grup osób dorosłych.

\section{Innowacja procesowa}

Szerszą definicję innowacji prezentuje Podręcznik Oslo, według którego innowacja (ang. innovation) jest „to wdrożenie nowego lub znacząco udoskonalonego produktu (wyrobu lub usługi) lub procesu, nowej metody marketingowej lub nowej metody organizacyjnej w praktyce gospodarczej, organizacji miejsca pracy lub stosunkach z otoczeniem" (Podręcznik Oslo, 2008: 48). Powyższa definicja wykracza poza produktowy wymiar innowacji i obejmuje również usprawnienie sposobu działania nie tylko w sferze gospodarczej, ale również we wszelkiego typu organizacji pracy i w relacjach między organizacją a otoczeniem.

Proces, procedura czy metodyka wdrażania i dystrybuowania innowacyjnych rozwiązań mogą być zatem również uznane za przejaw innowacyjności.

${ }^{1} \mathrm{O}$ innowacyjności gier Małopolskiego Instytutu Kultury świadczą: uzyskanie patronatu Europejskiego Roku Kreatywności i Innowacji 2009, otrzymanie wyróżnienia w konkursie „Europejskie Nagrody Promocji Przedsiębiorczości”, Nagrody Ministra Gospodarki RP w 2014 roku, a także licznych rekomendacji instytucji rynku pracy oraz edukacji, takich jak Uniwersytet Jagielloński czy Ośrodek Rozwoju Edukacji w Warszawie (więcej: http://csb.mik.krakow.pl/rekomendacje/). 


\section{Proces (cykl) innowacji}

Istnieje również trzecie, szerokie ujęcie problematyki innowacji, odnoszące się do cyklu (procesu) innowacji: od wypracowania koncepcji do jej dyfuzji, co przedstawione zostało na rycinie 1.

Ryc. 1. Ogólny model procesu (cyklu) innowacji

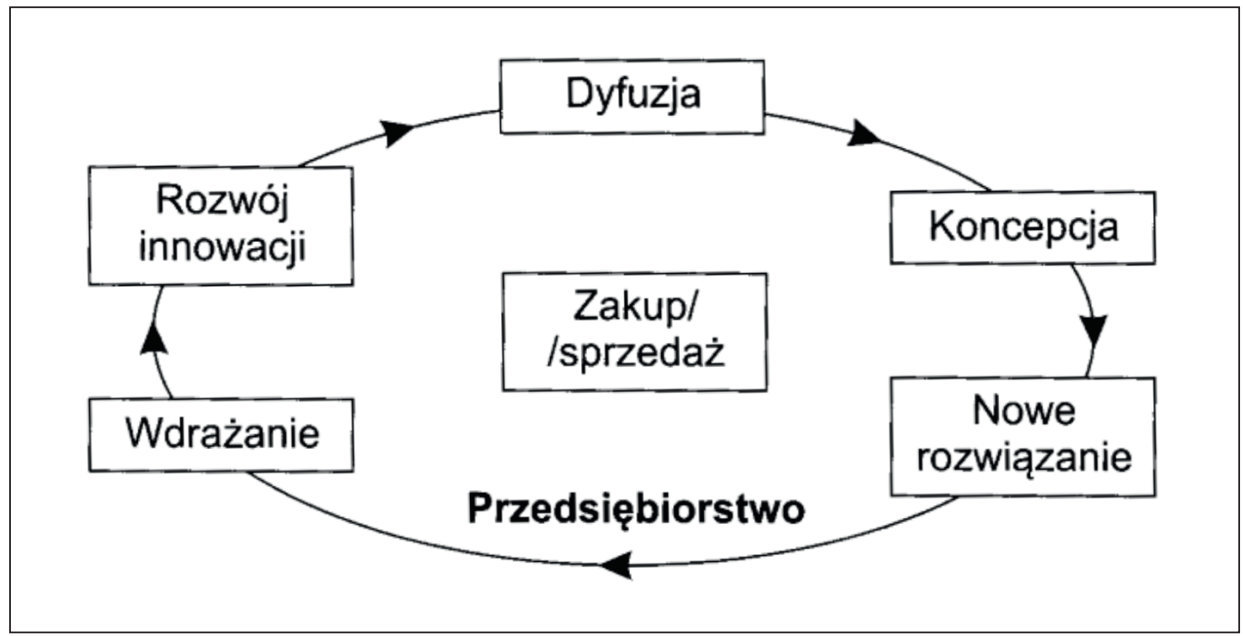

Źródło: Dolińska (2010: 13-15)

Wstępna koncepcja innowacji prowadzi do wypracowania nowego rozwiązania, które jest w organizacji wdrażane. Po przeprowadzeniu wdrożenia można zaobserwować rozwój innowacji: jej adaptację, nowe zastosowania lub rozszerzenie albo dalsze ulepszenia w organizacji, a następnie jej dyfuzję, czyli „rozpowszechnienie nowego pomysłu, rozwiązania od źródła, gdzie powstał, do akceptujących go ostatecznych użytkowników na rynkach” (Dolińska, 2010: 15). Ponadto, jak zauważyła Joanna Dolińska, „każda ze składowych czynności procesu, a także ich dowolny zestaw mogą być również procesem innowacji. Rezultat wykonania dowolnej czynności, zestawu czynności, całego procesu, który ma wartość rynkową, jest uznawany za innowację, jeśli została w nim wykorzystana nowa wiedza lub w nowy sposób istniejąca do tej pory wiedza” (Dolińska, 2010: 15)).

\section{Innowacje w edukacji}

W świetle powyższej definicji śmiało można mówić o innowacjach w sektorze edukacji. Mają one niewymierne, ale w dłuższym okresie istotne znaczenie dla rozwoju młodzieży: przyszłych obywateli i uczestników rynku pracy (przedsiębiorców albo pracobiorców). Zdaniem Damiana Ostrowskiego „to właśnie na poziomie szkół podstawowych i średnich kształtuje się osobowość człowieka, jego zdolność do kreatywności, przedsiębiorczości, innowacyjności. Dalszy etap to już swoiste pogłębianie ukształtowanych postaw i sposobów zachowania" (Ostrowski, 2011: 112).

Zakładamy, że innowacja edukacyjna to dowolne rozwiązanie wprowadzające jakościową zmianę na korzyć podmiotów uczących się, służące np. efektywnemu uczeniu się 
w szkołach (edukacja formalna) lub w ramach organizacji działających w środowisku pozaszkolnym (edukacja nieformalna) (por. Wittbrodt, 2007: 13).

W odniesieniu do polskiego sektora oświaty prowadzącego edukację formalną wdrożenia innowacji edukacyjnych mogą realizować szkoły, regionalne ośrodki doskonalenia nauczycieli podlegające władzom samorządowym, jak również wojewódzkie kuratoria oświaty podlegające władzy na szczeblu centralnym. W przypadku wdrażania i dyfuzji innowacji w edukacji nieformalnej mamy na myśli przede wszystkim instytucje publiczne nienależące do sektora oświaty, jak również organizacje, grupy i osoby podejmujące aktywności edukacyjne w ramach społeczeństwa obywatelskiego.

\section{Wdrożenie}

Jako wdrożenie rozumiemy wprowadzenie innowacji do użytku w ramach jednej organizacji.

\section{Dyfuzja}

Na potrzeby niniejszego artykułu przyjęto założenie, że dyfuzja innowacji oznacza serię wdrożeń innowacji w organizacjach.

Odgórny (instytucjonalny) i oddolny (społeczny) model wdrażania innowacji

Model odgórny (instytucjonalny), realizowany przez instytucje publiczne można nazwać również systemowym. Według Beaty Przyborowskiej „obok swego podstawowego znaczenia 'budowa czegoś', pojęcie struktury organizacyjnej używane bywa jako synonim wyrazu system - czyli coś, co ma określoną strukturę i utożsamiane jest z organizacją formalną" (Przyborowska, 2003: 17).

Model odgórny zakłada, że opracowana innowacja edukacyjna jest wdrażana skutecznie dzięki wykorzystaniu struktury organizacyjnej systemu oświaty. Wówczas formalne ustalenia i umowy na szczeblu dyrektorskim stanowią gwarancję skutecznej dyfuzji głównie w szkołach, a hierarchiczność i ograniczona elastyczność struktury organizacyjnej systemu oświatowego stanowią oparcie dla skutecznej dyfuzji (ryc. 2).

\section{System szkoleń kaskadowych}

Rycina 2 przedstawia strukturę organizacyjną odgórnej dyfuzji innowacji. W tym modelu dostawca innowacji (np. wydawca gry edukacyjnej, autor scenariuszy lekcji lub koncepcji nowatorskiego projektu edukacyjnego realizującego podstawę programową, internetowego serwisu edukacyjnego itp.) zawiera umowę z operatorem, czyli podmiotem sektora oświaty działającym na szczeblu centralnym lub regionalnym. Na mocy tej umowy prowadzone są następnie szkolenia kaskadowe dla przyszłych trenerów (nauczycieli, doradców lub konsultantów), którzy będą wspierać wdrożenia innowacji w szkołach przez lokalne szkolenia lub konsultacje dla początkujących użytkowników innowacji.

W „idealnych” warunkach dostawca innowacji przeprowadza szkolenie na szczeblu centralnym dla trenerów działających w regionalnych podmiotach sektora oświaty. $\mathrm{Na}$ regionalnym szczeblu odbywają się szkolenia prowadzone przez trenerów regionalnych, 
Ryc. 2. Model odgórny (instytucjonalny, systemowy) dyfuzji innowacji edukacyjnych

\begin{tabular}{|c|c|c|c|c|c|}
\hline $\begin{array}{l}\text { DOSTAWCA } \\
\text { INNOWACJI }\end{array}$ & & \multicolumn{3}{|c|}{$\begin{array}{l}\text { OPERATOR - CENTRALNY PODMIOT } \\
\text { SEKTORA OŚWIATY } \\
\text { (szkolenie inicjujące dyfuzję innowacji) }\end{array}$} & \\
\hline $\begin{array}{l}\text { REGIONALNY } \\
\text { PODMIOT } \\
\text { SEKTORA } \\
\text { OŚWIATY }\end{array}$ & & & $\begin{array}{c}\text { REGIONALNY } \\
\text { PODMIOT } \\
\text { SEKTORA } \\
\text { OŚWIATY }\end{array}$ & & $\begin{array}{c}\text { REGIONALNY } \\
\text { PODMIOT } \\
\text { SEKTORA } \\
\text { OŚWIATY }\end{array}$ \\
\hline $\begin{array}{l}\text { LOKALNY } \\
\text { PODMIOT } \\
\text { SEKTORA } \\
\text { OŚWIATY } \\
\text { (SZKOŁA) }\end{array}$ & $\begin{array}{l}\text { LOKALNY } \\
\text { PODMIOT } \\
\text { SEKTORA } \\
\text { OŚWIATY } \\
\text { (SZKOŁA) }\end{array}$ & $\begin{array}{l}\text { LOKALNY } \\
\text { PODMIOT } \\
\text { SEKTORA } \\
\text { OŚWIATY } \\
\text { (SZKOŁA) }\end{array}$ & $\begin{array}{l}\text { LOKALNY } \\
\text { PODMIOT } \\
\text { SEKTORA } \\
\text { OŚWIATY } \\
\text { (SZKOŁA) }\end{array}$ & $\begin{array}{l}\text { LOKALNY } \\
\text { PODMIOT } \\
\text { SEKTORA } \\
\text { OŚWIATY } \\
\text { (SZKOŁA) }\end{array}$ & $\begin{array}{l}\text { LOKALNY } \\
\text { PODMIOT } \\
\text { SEKTORA } \\
\text { OŚWIATY } \\
\text { (SZKOŁA) }\end{array}$ \\
\hline
\end{tabular}

Źródło: opracowanie własne

skierowane do osób działających w podmiotach lokalnych. Szkoleniom tym towarzyszą konsultacje udzielano odpowiednio:

- trenerom regionalnym przez dostawcę innowacji,

- użytkownikom innowacji w lokalnych podmiotach sektora oświaty przez regionalnych trenerów.

Poniżej zebrano podział kompetencji w ramach odgórnej dyfuzji innowacji edukacyjnej.

Ryc. 3. Podział zadań w ramach odgórnej dyfuzji innowacji edukacyjnych

\begin{tabular}{|c|c|c|c|}
\hline $\begin{array}{l}\text { DOSTAWCA } \\
\text { INNOWACJI }\end{array}$ & $\begin{array}{c}\text { CENTRALNY } \\
\text { PODMIOT } \\
\text { SEKTORA OŚWIATY } \\
\text { (OPERATOR) }\end{array}$ & $\begin{array}{c}\text { REGIONALNY } \\
\text { PODMIOT } \\
\text { SEKTORA OŚWIATY }\end{array}$ & $\begin{array}{l}\text { LOKALNY PODMIOT } \\
\text { SEKTORA OŚWIATY } \\
\text { (UŻYTKOWNIK) }\end{array}$ \\
\hline $\begin{array}{l}\text { - przekazanie innowacji } \\
\text { do centralnego, } \\
\text { regionalnego lub } \\
\text { lokalnego podmiotu } \\
\text { oświaty } \\
\text { - przeszkolenie } \\
\text { trenerów ds. innowacji } \\
\text { w regionach } \\
\text { - konsultacje dla } \\
\text { regionalnych trenerów } \\
\text { innowacji }\end{array}$ & $\begin{array}{l}\text { - } \text { rekrutacja trenerów } \\
\text { regionalnych innowacji } \\
\text { - zapewnienie warunków } \\
\text { do realizacji szkoleń } \\
\text { dla trenerów przez } \\
\text { dostawcę innowacji } \\
\text { - pośrednictwo między } \\
\text { trenerami regionalnymi } \\
\text { a dostawcą innowacji }\end{array}$ & $\begin{array}{l}\text { - } \text { rekrutacja } \\
\text { użytkowników } \\
\text { w regionie - lokalnych } \\
\text { podmiotów sektora } \\
\text { oświaty } \\
\text { - zapewnienie warunków } \\
\text { do realizacji szkolenia } \\
\text { przez dostawcę lub } \\
\text { trenerów regionalnych } \\
\text { innowacji } \\
\text { - konsultacje dla } \\
\text { użytkowników }\end{array}$ & $\begin{array}{l}\text { - uczestnictwo } \\
\text { w szkoleniu } \\
\text { - } \text { konsultacje z trenerem } \\
\text { innowacji } \\
\text { - wdrożenie } \\
\text { (wykorzystanie } \\
\text { innowacji co najmniej } \\
\text { w zakresie ustalonym } \\
\text { w umowie z dostawcą } \\
\text { lub podmiotem, który } \\
\text { przekazał innowację) }\end{array}$ \\
\hline
\end{tabular}

Źródło: opracowanie własne 
W polskich regionach funkcjonują regionalne ośrodki doskonalenia nauczycieli, podlegające władzom samorządowym (odpowiednim pionom w urzędach marszałkowskich). Ośrodki te zajmują się na co dzień doszkalaniem nauczycieli, współpracą ze szkołami w powiatach itp. Oprócz tego w systemie oświatowym istnieje również Ośrodek Rozwoju Edukacji, który jest „publiczną placówką doskonalenia nauczycieli o zasięgu ogólnokrajowym podlegającą bezpośrednio Ministerstwu Edukacji Narodowej” (Ośrodek...).

W zrealizowanych projektach edukacyjnych Małopolski Instytut Kultury w Krakowie pełnił funkcję dostawcy innowacji, który podejmował współpracę z Ośrodkiem Rozwoju Edukacji (operatorem - centralnym podmiotem sektora oświaty) oraz z regionalnymi ośrodkami doskonalenia nauczycieli w trzech województwach: Małopolskim Centrum Doskonalenia Nauczycieli, Świętokrzyskim Centrum Doskonalenia Nauczycieli oraz Podkarpackim Centrum Edukacji Nauczycieli.

W projekcie dofinansowanym przez Muzeum Historii Polski poświęconym edukacji ekonomicznej w oparciu o losy pionierów przemysłu naftowego działających w austro-węgierskiej w Galicji, Ośrodek Rozwoju Edukacji pełniący funkcję operatora z sektora oświaty przeprowadził rekrutację kilkunastu nauczycieli z 10 województw w Polsce, którzy po przeszkoleniu stali się lokalnymi trenerami i dystrybutorami w szkołach historyczno-ekonomicznej gry naftowej Oil City - galicyjska gorączka czarnego złota. Mimo ograniczonego nakładu przeznaczonego do dystrybucji instytucjonalnej za pośrednictwem operatora z sektora oświaty (100 egzemplarzy) oraz mimo niezwykle krótkiego czasu realizacji działań edukacyjnych (wrzesień-grudzień 2015), a także mimo braku środków na kampanię promocyjną w projekcie udało się w ciągu kilku miesięcy dotrzeć do ponad 4000 uczniów. Było to możliwe dzięki zastosowaniu systemu szkoleń kaskadowych we współpracy z Ośrodkiem Rozwoju Edukacji w Warszawie. Szkolenia uzupełniane były konsultacyjno-wdrożeniowymi sesjami wideo, z wykorzystaniem internetu.

Szkoleni w ramach tego projektu nauczyciele mogli zapoznać się z historią 16 zapomnianych pionierów przemysłu naftowego w Galicji (trzeciego na świecie ośrodka wydobywczego po Rosji i Stanach Zjednoczonych), których życiorysy zamieszczono na stronie internetowej: www.oc.mik.krakow.pl/pionierzy/, oraz z grą edukacyjną, której mechanizm nawiązywał do prowadzenia biznesu naftowego w warunkach gwałtownych zmian cen surowców (przedestylowanej ropy naftowej, wosku i gazu ziemnego) i kryzysu nadprodukcji „czarnego złota” na początku XX w. Uczestnicy działają w grze jako przedsiębiorcy ponoszący ryzyko inwestycji w sprzęt wydobywczy, a następnie prowadzą wydobycie i destylację ropy naftowej oraz sprzedaż pozyskanych surowców przy zmieniających się cenach.

Dzięki zastosowaniu systemu szkoleń kaskadowych odbyły się dwa szkolenia inicjujące kaskadę szkoleniową dla 14 koordynatorów regionalnych oraz 14 szkoleń w regionach dla 183 nauczycieli. W wyniku przeprowadzonej akcji szkoleniowej i konsultacyjnej w zajęciach z wykorzystaniem gry Oil City wzięło udział ponad 4000 uczniów. Na uwagę zasługuje efektywność „kaskadowej” struktury organizacji i komunikacji w ramach przeprowadzonej dyfuzji: kilku inicjatorów z ramienia dostawcy innowacji przekłada się na kilkunastu przeszkolonych trenerów w regionach, niemal 200 nauczycieli-użytkowników innowacji oraz 4000 uczniów uczących się przedsiębiorczego działania za pomocą gry symulacyjnej przeprowadzonej w szkołach przez nauczycieli przedsiębiorczości, historii, wiedzy o społeczeństwie i geografii. 


\section{Oddolny (społecznościowy, pomocniczy) model dyfuzji innowacji}

Oddolny model wdrażania innowacji opiera się na aktywności podmiotów lokalnych. W tym modelu innowacja edukacyjna wpisuje się w istniejącą już działalność podmiotu lokalnego (np. szkoły, organizacji pozarządowej, aktywnego obywatela lub grupy osób) i opiera się na zasadzie pomocniczości. Według tej zasady wszelka pomoc (interwencja) powinna ograniczać się do koniecznego minimum w myśl dewizy „Tyle wolności, ile możliwe, tyle władzy, ile konieczne" (por. Czapska, 2012; Millon-Delsol, 1995; Wyka, 2004). Głównym podmiotem (aktorem) w relacji opartej na zasadzie pomocniczości jest lokalny, działający autonomicznie podmiot, np. szkoła, organizacja pozarządowa, aktywna grupa społeczna, obywatel itp. Natomiast dostawca innowacji odgrywa w tej relacji rolę podmiotu pomocniczego wobec aktora, czyli aktywnego, lokalnego podmiotu.

Punktem wyjścia w oddolnym modelu jest aktywność i potrzeba wykorzystania innowacji ze strony lokalnego podmiotu (aktora), który zgłasza chęć wdrożenia innowacji w ramach swoich działań edukacyjnych (np. w ramach wydarzenia lokalnego, podczas lekcji, zajęć pozalekcyjnych, wycieczki, lokalnego turnieju itp.). Wówczas dostawca innowacji przekazuje aktorowi know-how związane z innowacją oraz udziela koniecznego wsparcia i konsultacji. Poniżej przedstawiono podział kompetencji w ramach oddolnego modelu wdrażania innowacji.

Ryc. 4. Podział kompetencji w ramach oddolnego (pomocniczego) modelu dyfuzji innowacji

\begin{tabular}{|l|}
\hline \multicolumn{1}{|c|}{ DOSTAWCA INNOWACJI } \\
(PODMIOT POMOCNICZY) \\
\hline - umowa - ustalona minimalna frekwencja \\
- przekazanie innowacji edukacyjnej \\
- udzielanie koniecznego wsparcia \\
- konsultacje wdrożeniowe \\
\end{tabular}

\begin{tabular}{|c|}
\hline \multicolumn{1}{|c|}{ PODMIOT LOKALNY } \\
(INICJATOR I KOORDYNATOR DZIAŁAŃ) \\
\hline - własny pomysł na inicjatywę edukacyjną \\
- zapewnienie minimalnej umówionej frekwencji \\
w ramach własnej inicjatywy \\
- rozwój własnych kompetencji i możliwości \\
działania \\
- zaangażowanie partnerów lokalnych
\end{tabular}

Źródło: opracowanie własne

W odróżnieniu od kaskady szkoleniowej, która jest ważnym czynnikiem efektywności w odgórnym modelu dyfuzji innowacji, model oddolny opiera się na dwustronnych relacjach między dostawcą innowacji a lokalnym podmiotem - użytkownikiem, który wdraża innowację we własnych działaniach. Struktura organizacyjna jest w tym modelu płaska w odróżnieniu od kilkuszczeblowej struktury organizacyjnej występującej w modelu odgórnym.

Ryc. 5. Oddolny model (pomocniczy, lokalny) dyfuzji innowacji edukacyjnych

\begin{tabular}{|c|c|c|c|c|}
\hline \multicolumn{5}{|c|}{ DOSTAWCA INNOWACJI } \\
\hline $\begin{array}{l}\text { - lokalny podmiot } \\
\text { - prowadzący } \\
\text { działalność } \\
\text { edukacyjną }\end{array}$ & $\begin{array}{l}\text { - lokalny podmiot } \\
\text { - prowadzący } \\
\text { działalność } \\
\text { edukacyjna }\end{array}$ & $\begin{array}{l}\text { - lokalny podmiot } \\
\text { - prowadzący } \\
\text { działalność } \\
\text { edukacyjną }\end{array}$ & $\begin{array}{l}\text { - lokalny podmiot } \\
\text { - prowadzący } \\
\text { działalność } \\
\text { edukacyjna }\end{array}$ & - $[\ldots]$ \\
\hline
\end{tabular}

Źródło: opracowanie własne 


\section{Jak wygląda realizacja w praktyce oddolnego modelu dyfuzji innowacji edukacyjnej?}

W okresie od czerwca 2012 r. do kwietnia 2013 r. Małopolski Instytut Kultury w Krakowie zrealizował ogólnopolski projekt edukacyjny dofinansowany przez Narodowy Bank Polski oraz Gminę Andrychów. Głównym celem projektu było pobudzanie postaw przedsiębiorczych i rozwój kompetencji społecznych wśród młodzieży szkolnej. Do pozostałych celów należała popularyzacja wiedzy ekonomicznej, zwłaszcza upowszechnianie wiedzy o zasadach funkcjonowania gospodarki rynkowej. Działania edukacyjne opierały się na grze symulacyjnej Chłopska Szkoła Biznesu, która nawiązuje do historii przedsiębiorczych tkaczy z XVIII-wiecznego Andrychowa i uczy graczy planowania, współpracy w spółkach oraz działania w warunkach wolnego rynku. Innowacyjność gry polega m.in. na tym, że w rozgrywce, która trwa do 45 min, może wziąć udział od 12 do 30 osób, które doświadczają działania podstawowych zjawisk i praw ekonomicznych symulowanych w grze (zarówno mikroekonomicznych, jak i makroekonomicznych) (zob. Rusin, Wacięga, 2014).

Wyżej wymieniony projekt składał się z trzech modułów (Kicińska, Sarlej, Wacięga, 2013: 4):

- modułu szkoleniowego dla nauczycieli przeprowadzonego we współpracy z regionalnymi ośrodkami doskonalenia nauczycieli (217 uczestników szkoleń),

- modułu turniejowego (4 720 uczniów, którzy wzięli udział w rozgrywkach turniejowych Chłopskiej Szkoły Biznesu),

- modułu dla uczestników oddolnych inicjatyw edukacyjnych, którym wzięło udział aż 10944 osób.

Dwa pierwsze moduły zostały ściśle odgórnie zaplanowane (partnerzy, zakładana frekwencja, terminy itp.), natomiast moduł trzeci, oddolny, miał określone jedynie ramowo warunki współpracy z partnerami lokalnymi, którzy zgłaszali się do dystrybutorów innowacji (Małopolskiego Instytutu Kultury oraz Urzędu Miasta Andrychów). Głównym wymaganiem dystrybutora innowacji wobec partnerów - lokalnych podmiotów podejmujących działania edukacyjne było przeprowadzenie zajęć dla minimalnej liczby 90 osób. Odpowiedzialność za pomysł na realizację lokalnej inicjatywy z grą (np. lekcji, warsztatów, turnieju lub imprezy lokalnej z komponentem edukacji ekonomicznej) oraz jego realizacja leżały po stronie partnera - lokalnego podmiotu.

Stopień zaangażowania lokalnych podmiotów oraz skala przerosły oczekiwania autora projektu (dystrybutora innowacji): na 15881 uczestników projektu aż 69\% (10 944 osób) włączyło się do działań projektowych w ramach oddolnych inicjatyw. Rekordzistami frekwencyjnymi okazały się: III Liceum Ogólnokształcące w Toruniu, które zorganizowało rozgrywki dla 900 osób łącznie, oraz Stowarzyszenie Szanse Bezdroży Gmin Powiatu Goleniowskiego, które zainicjowało powiatowy turniej Chłopskiej Szkoły Biznesu z udziałem 646 osób. Na uwagę zasługuje struktura podmiotów zainteresowanych zastosowaniem u siebie innowacji edukacyjnej. Aż 52\% zgłoszeń stanowiły szkoły (podstawowe, gimnazjalne i ponadgimnazjalne), następnie biblioteki (13\%), organizacje pozarządowe (12\%), uczelnie wyższe, muzea i firmy o profilu szkoleniowo-edukacyjnym (5\%), ośrodki kultury i instytucje rynku pracy (po 3\%) i inne (2\%) (Kicińska, Sarlej, Wacięga, 2013).

Dodatkowymi, nieprzewidzianymi w projekcie skutkami przeprowadzonej oddolnie dyfuzji było powstawanie lokalnych partnerstw - zapraszanie do współpracy kolejnych lokalnych podmiotów, aby lokalne podmioty edukacyjne mogły zrealizować inicjatywę 
i wywiązać się z umowy z dostawcą innowacji (bezpłatny egzemplarz gry w zamian za zrealizowanie własnej inicjatywy dla określonej minimalnej liczby osób). Często, aby sprostać wymaganiom projektu, lokalne podmioty nawiązywały współpracę z lokalnymi partnerami. W ten sposób na 85 zrealizowanych w projekcie inicjatyw oddolnych przypadło dodatkowo 108 partnerów zaproszonych do współpracy w działaniach edukacyjnych (Kicińska, Sarlej, Wacięga, 2013: 12).

Cechą dyfuzji innowacji edukacyjnej przeprowadzonej za pomocą oddolnego modelu była jej wysoka efektywność (mierzona frekwencją) oraz zawiązywanie się lokalnej współpracy i partnerstw. Jego ujemną stroną było ryzyko związane z niewystarczającymi kompetencjami wdrożeniowymi i organizacyjnymi, których nie był w stanie zniwelować u partnerów dostawca innowacji (podmiot pomocniczy). W przypadku powyższego projektu 6 podmiotów (na 88 zgłoszonych inicjatyw) nie było w stanie wywiązać się z umowy z dystrybutorem innowacji. A zatem „strata” (mierzona liczbą niezrealizowanych w pełni 6 inicjatyw do 88 zgłoszonych) wyniosła w oddolnym modelu mniej niemal 7\% inicjatyw ogółem.

\section{Podsumowanie}

Do skutecznego wdrożenia innowacji w organizacji konieczny jest adekwatny dobór środków ułatwiających wdrożenie innowacji (np. szkolenia, konsultacje, telekonferencje, nauka w działaniu z grupami pilotażowymi), czyli właściwe wsparcie ze strony dostawcy innowacji dla użytkownika innowacji, uwzględniające jego możliwości i ograniczenia. Natomiast sterowana dyfuzja innowacji, czyli skoordynowane doprowadzenie do wdrożeń na szerszą skalę, wymaga wyboru modelu, który zagwarantuje optymalną efektywność przy realizacji zmultiplikowanych wdrożeń. Powyżej zaproponowano dwa wybrane modele dyfuzji innowacji edukacyjnych. Pierwszy, odgórny, daje dystrybutorowi innowacji lub operatorowi większą kontrolę nad procesem dyfuzji, ale nie wykorzystuje w pełni potencjału aktywności i współpracy ukrytego w lokalnych społecznościach. Drugi, oddolny, wiąże się z mniejszą kontrolą nad procesem dyfuzji innowacji edukacyjnej, a więc większym ryzykiem projektowym. Może on jednak pełniej uruchamiać potencjał lokalnej aktywności i współpracy, który ma szersze (społeczne, obywatelskie) znaczenie niż wyłącznie skuteczność we wdrożeniu i dyfuzji innowacji edukacyjnej.

Niezależnie od preferowanego modelu, skuteczna dyfuzja innowacji edukacyjnych polega na stworzeniu warunków, w których innowacja edukacyjna może zostać właściwie zrozumiana, przyswojona, a następnie wdrożona i zaadaptowana przez lokalnych użytkowników stosownie do ich potrzeb i możliwości. Friedrich Ratzel, który wyjaśniał zjawisko dyfuzji i innowacji na gruncie antropogeografii, zauważył, że „dyfuzja innowacji nie polega bowiem jedynie na tym, by przedmiot zmienił swoje położenie geograficzne. Sens dyfuzji tkwi w tym, by nowy przedmiot został przyjęty i w sensowny sposób użytkowany. [...] Zastosowanie niektórych innowacji wymaga szczegółowego instruktażu, podczas gdy inne stosowane mogą być przez kolejnych na drodze prostego naśladownictwa" (Zdun, 2016: 191).

Istotnym czynnikiem, który przesądza o skutecznym wdrażaniu i dyfuzji innowacji, jest tzw. kompetencja innowacyjna jej potencjalnego użytkownika. Psycholog Zbigniew Pietrasiński odnosi to pojęcie do jednostek ludzkich i rozumie je jako „stosunkowo najbardziej bezpośrednie przygotowanie do wprowadzenia innowacji, oparte na przyswojeniu 
doświadczeń praktycznych i odpowiedniej wiedzy naukowej” (Przyborowska, 2003: 142 za: Pietrasiński, 1970: 10). Rozszerzone pojęcie „kompetencji innowacyjnych” odnosi się również do nowatorstwa organizacji oraz opiera się na jej „kompetencjach w zakresie przyswajania innowacji i wprowadzania zmian”. Kluczowe znaczenie dla dyfuzji innowacji edukacyjnych ma również innowacyjność instytucji dostarczających i wspierających procesy wdrażania i dyfuzji innowacji (technicznych, jak i społecznych) w regionach, takich jak instytucje rynku pracy, ośrodki doskonalenia zawodowego nauczycieli czy instytucje kultury. Powinna je cechować „innowacyjność [...] jako zdolność organizacji do stałego poszukiwania, wdrażania i upowszechniania innowacji” (Przyborowska, 2003: 143 za: Pomykalski, 2001: 13), czyli kompetencja innowacyjna, rozumiana jako „zdolność do twórczego udziału w procesach innowacyjnych”2 (Przyborowska, 2003: 143 za: Suchanek 1983: 17). Procesach innowacyjnych rozumianych również jako procesy odnowy sektora edukacji, zgodnie z łacińskim źródłosłowem pojęcia innowacji, którym jest słowo innovare, czyli 'odnawiać' (Weresa, 2014).

Literatura

References

Chłopska Szkoła Biznesu. Rekomendacje (2017, 20 października). http://csb.mik.krakow.pl/rekomendacjel

Czapska, E. (2012). O zasadzie pomocniczości. Realia. Dwumiesięcznik społeczno-polityczny, 1(27). Pozyskano z: http://realia.com.pl/dzial_1/artykul_35.html

Innowacja i transfer technologii. Słownik pojęć. (2005). Warszawa: Polska Agencja Rozwoju Przedsiębiorczości.

Dolińska, J. (2010). Innowacje w gospodarce opartej na wiedzy. Warszawa: PWE.

Millon-Delsol, Ch. (1995). Zasada pomocniczości. Kraków: Znak.

Ostrowski, D. (2011). Model realizacji procedury strategicznej w placówce oświatowej. W: J. Czekaj, B. Mikuła, R. Oczkowska, J. Teczke (red.), Nauka i gospodarka $w$ dobie destabilizacji. Kraków: UEK, $111-118$.

Ośrodek Rozwoju Edukacji. (2017, 20 października). O Ośrodku, https://www.ore.edu.pl/o-nas/struktura-ore

Pietrasiński, Z. (1970). Ogólne i psychologiczne zagadnienia innowacji. Warszawa: PWN.

Podręcznik Oslo. Zasady gromadzenia i interpretacji danych dotyczacych innowacji. Wydanie trzecie. (2008). Warszawa: OECD i Eurostat

Kicińska, M., Sarlej, A., Wacięga, S. (2013). Projekt Edukacja ekonomiczna z wykorzystaniem gry symulacyjnej „Chłopska Szkoła Biznesu”. Sprawozdanie merytoryczne. Kraków: Małopolski Instytut Kultury. Pozyskano z: http://mik.krakow.pl/wp-content/uploads/CSBNBP_sprawozdanie_ raport_V2013.pdf

Pietrasiński, Z. (1970). Ogólne i psychologiczne zagadnienia innowacji. Warszawa: PWN.

Pomykalski, A. (2001). Zarzadzanie innowacjami. Warszawa: PWN.

Przyborowska, B. (2003). Struktury innowacyjne w edukacji. Teoria. Praktyka. Rozwój. Toruń: Wydawnictwo UMK

Rusin, D., Wacięga, S. (2014). Edukacja ekonomiczna w oparciu o historię. Przypadek Andrychowa (2007-2014). Kwartalnik Edukacyjny, 4(79). Pozyskano z: http://mik.krakow.pl/wp-content/uploads/kwartalnik_edukacyjny_CSB.pdf

Suchanek, A. (1983). Innowacje oświatowe. Kalisz: WODN.

\footnotetext{
${ }^{2}$ Przyborowska B. (2003) za: Suchanek (1983: 17).
} 
Wacięga, S. (2015). Practical use of knowledge about history for entrepreneurial learning. The sketch of the method. In: M. Makowiec, T. Kusio (red.), Management of entrepreneurship in a knowledge based economy. The issue of knowledge and intellectual capital management. Kraków: Uniwersytet Ekonomiczny.

Wittbrodt, E. (2007). Contemporary Educational Challenge. In: E. Walkiewicz (red.). Lifelong Learning in the Context of Development of Civil Society. Warszawa-Gdańsk.

Weresa, M.A. (2014). Polityka innowacyjna. Warszawa: PWN.

Wyka, A. (2004). Co się dzieje z zasadą pomocniczości w Polsce?. ALTER. Pozyskano z: http://www. swietoradosci.most.org.pl/alter/wyka_co-sie-dzieje-z-zasada-pomocniczosci.htm

Zdun, M. (2016). Innowacje. Perspektywa społeczno-kulturowa. Lublin: Wydawnictwo KUL.

Sebastian Wacięga, dr, od 2004 r. związany z Małopolskim Instytutem w Krakowie, gdzie współpracuje z zespołami instytucji kultury jako facylitator planowania strategicznego. Współtwórca gier symulacyjnych inspirowanych historią: Oil City - galicyjska gorączka czarnego złota (2015) o XIX-wiecznych pionierach przemysłu naftowego oraz Chłopska Szkoła Biznesu (2010, 2012, 2015) o przedsiębiorczości w XVIII-wiecznym andrychowskim ośrodku tkackim. Uczestniczył w tworzeniu koncepcji i realizacji: wystaw i wydarzeń kulturalnych, warsztatów edukacyjnych i szkoleń dla osób pracujących w instytucjach kultury, organizacjach pozarządowych, instytucjach rynku pracy, firmach oraz dla uczniów i osób bezrobotnych. Współautor książki Lokalne muzeum w globalnym świecie. Poradnik praktyczny (2013). Ukończył studia ekonomiczne (specjalność: przedsiębiorczość i innowacje) oraz kulturoznawcze (specjalność: europeistyka). Obronił doktorat na temat pomocniczości w lokalnej współpracy. Zainteresowany praktycznym zastosowaniem dziedzictwa, zwłaszcza do celów szkoleniowych i edukacyjnych.

Sebastian Wacięga, PhD at the Malopolska Institute of Culture in Krakow (Poland), where he cooperates with teams of social and public institutions as a facilitator of strategic planning. Co-creator of economic simulation games inspired by regional history: Oil City - Black Gold Fever in Galicia (2015) and the Peasant School of Business $(2010,2012,2015)$ about 18th century entrepreneurs from Andrychów who exported $80 \%$ of their flaxen fabrics. Co-creator and developer of numerous concepts of exhibitions, cultural events, workshops and trainings for cultural institutions, NGOs, labour market organisations, companies, as well as pupils and the unemployed. Co-author of the book A Local Museum in a Global World. Practical Handbook (2013). MA in Economics (specialisation: entrepreneurship and innovations) and MA in Cultural Studies (specialisation: European Studies). PhD at the Institute of European Studies, The Jagiellonian University in Cracow (Poland) with dissertation on subsidiarity in local cooperation.

\section{Adres/Address:}

Małopolski Instytut Kultury w Krakowie

ul. 28 Lipca $194317 \mathrm{c}$

30-233 Kraków, Polska

Piotr Wróbel, mgr, nauczyciel dyplomowany podstaw przedsiębiorczości i ekonomii w praktyce w VII Liceum Ogólnokształcącym im. Zofii Nałkowskiej w Krakowie, III Społecznym Liceum Ogólnokształcącym im. Juliusza Słowackiego w Krakowie oraz III Prywatnym Liceum Ogólnokształcącym w Krakowie. Doradca zawodowy. Doktorant w Akademii Górniczo-Hutniczej w Krakowie. Członek Zarządu Fundacji „Znaczenie”. Pilot wycieczek krajowych i zagranicznych, rezydent. Jego zainteresowania badawcze ukierunkowane są przede wszystkim na zarządzanie oświatą i zarządzanie w turystyce, jak również na problematykę nauczania przedsiębiorczości w szkole.

Piotr Wróbel, MA, certified teacher of entrepreneurship and economics in practice at Zofia Nałkowska High School no 7 in Krakow, Juliusz Słowacki Community High School no 3 in Krakow, and Private High School no 3 in Krakow. Career counsellor. PhD candidate at AGH University of 
Science and Technology in Krakow. Board member in the Znaczenie Foundation. Tour guide for tours in Poland and abroad. His research is focused on management in education and tourism, as well as entrepreneurship school teaching.

\section{Adres/Address:}

VII Liceum Ogólnokształcące im. Zofii Nałkowskiej w Krakowie

ul. Stanisława Skarbińskiego 5

30-071 Kraków

e-mail: wrobus@wp.pl 